\title{
PENGARUH PENERAPAN STRATEGI PELAKSANAAN KELUARGA TERHADAP KEMAMPUAN KELUARGA MERAWAT PASIEN HALUSINASI DI KOTA JAMBI TAHUN 2017
}

\author{
Vevi Suryenti Putri ${ }^{1}$, Trimusarofah ${ }^{2}$ \\ 1,2Program Studi S1 Keperawatan STIKes Baiturrahim Jambi, Jambi \\ Email:vevisuryentiputri.2010@gmail.com
}

\begin{abstract}
Schizophrenic patients $70 \%$ have hallucinations. Nursing in caring for patients with hallucinations namely performance strategy execution for individual or family. Family's performance strategy is one nursing interventions for patients who are rarely hallucinated to the family. This study aimed to determine is there any affect of family's performance strategy execution toward the ability of family caring hallucinations patients. This is a quantitative research; it used pre experiment method and used one group pretest and posttest design. Samples were 20 respondents. This study was conducted from July $25^{\text {th }}$ - August 10 $0^{\text {th }} 2017$, data were collected using instruments in the form of interview and observation sheets. Data analized by using t-test. The average ability of families before being given family's performance strategy with average score (3.75) to be (5.75) after being given family's performance strategy. There is different of family's performance strategy execution toward the ability of family caring for hallucinations patients at Jambi city with p-value $0.00(<0.05)$. it conclude that there is the effect of family's performance strategy execuation toward the ability of family caring for hallucinations patients.
\end{abstract}

Key note : Family's Performance Strategy and The Ability of Family.

\begin{abstract}
ABSTRAK
Pasien skizofrenia 70\% pasien mengalami halusinasi. Tindakan keperawatan untuk menangani pasien dengan halusinasi yaitu penerapan strategi pelaksanaan baik untuk individu maupun keluarga. Strategi pelaksanaan keluarga merupakan salah satu intervensi keperawatan untuk pasien halusinasi yang jarang dilakukan kepada keluarga. Tujuan penelitian yaitu untuk mengetahui apakah ada pengaruh penerapan strategi pelaksanaan keluarga terhadap kemampuan keluarga merawat pasien halusinasi. Penelitian ini merupakan penelitian kuantitatif dengan metode penelitian pre eksperiment dengan desain penelitian one group pretest dan posttest. Sampel di pilih secara acak sebanyak 20 responden. Penelitian ini telah dilakukan dari tanggal 25 Juli - 10 Agustus 2017, data dikumpulkan menggunakan instrument berupa lembar wawancara dan observasi. Data dianalisisis menggunakan uji statistik t-test. Rata-rata kemampuan keluarga sebelum di berikan strategi pelaksanaan keluarga dengan nilai rata-rata (3.75) menjadi (5.75) sesudah diberikan strategi pelaksanaan keluarga. Terdapat perbedaan penerapan strategi pelaksanaan keluarga terhadap kemampuan keluarga merawat pasien halusinasi di Kota Jambi dengan $p$-value $0,00(<0,05)$. Hasil penelitian ini dapat disimpulkan bahwa ada pengaruh penerapan strategi pelaksanaan keluarga terhadap kemampuan keluarga merawat pasien halusinasi.
\end{abstract}

Kata kunci : Strategi Pelaksanaan Keluarga dan Kemampuan Keluarga 


\section{PENDAHULUAN}

\section{Menurut World Health Organization (2009) memperkirakan} 450 juta orang di seluruh dunia mengalami gangguan jiwa, sekitar $10 \%$ orang dewasa mengalami gangguan jiwa saat ini dan $25 \%$ penduduk diperkirakan akan mengalami gangguan jiwa pada usia tertentu selama hidupnya. Di Indonesia peningkatan jumlah penderita gangguan jiwa cukup banyak hal ini dikarenakan dari berbagai aspek misalnya keadaan ekonomi yang rendah, konflik yang sering terjadi, bencana dimana-mana. Di perkirakan jumlah penderita sebanyak 2-3 \%. Hasil Riset Kesehatan Dasar (Riskesdas) 2013 menunjukkan bahwa penderita gangguan jiwa berat di Indonesia adalah 1,7 per 1.000 orang. Riskesdas 2013 turut mencatat proporsi rumah tangga dengan minimal salah satu rumah tangga mengalami gangguan jiwa berat dan pernah dipasung mencapai 18,2 persen di daerah pedesaan. Sementara di daerah perkotaan, proporsinya mencapai 10,7 persen (Riskesdas Depkes RI, 2013).

Menurut Riskesdas 2013 angka prevelensi seumur hidup skizofrenia di dunia bervariasi berkisar 4 per mil sampai dengan $1,4 \%$. Berdasarkan Riskesdas 2013 prevelensi skizofrenia tertinggi di DI Yogyakarta dan Aceh (masing-masing 2,7\%), sedangkan yang terendah di Kalimantan Barat ( 0,7 \% ). Di Provinsi Jambi sendiri prevelensi skizofrenia yaitu $0,9 \%$.

Berdasarkan data Rekam Medis Rumah Sakit Jiwa Daerah Provinsi Jambi, jumlah kunjungan penderita skizofrenia pada tahun 2015 sebanyak 6.703 penderita, dan untuk jumlah penderita skizofrenia pada tahun 2016 sebanyak 8.994 penderita, sedangkan jumlah kunjungan terbaru per Mei 2017 yaitu sebanyak 3.642 penderita.

Menurut Yosep \& Sutini 2016 pada pasien skizofrenia, $70 \%$ pasien mengalami halusinasi. Halusinasi adalah gangguan penerimaan pancaindra tanpa stimulasi eksternal (halusinasi pendengaran, penglihatan, pengecapan, penciuman, dan perabaan). Halusinasi merupakan salah satu gejala gangguan jiwa pada individu yang di tandai dengan perubahan sensori persepsi; merasakan sensasi palsu berupa suara, penglihatan, pengecapan perabaan atau penghiduan. Pasien merasakan stimulus yang sebenarnya tidak ada ( Keliat, 2014).

Stuart dan Laraia dalam Yosep ( 2016 ) menyatakan bahwa pasien dengan halusinasi dengan diagnosa medis skizofrenia sebanyak $20 \%$ mengalami halusinasi pendengaran dan penglihatan secara bersamaan, $70 \%$ mengalami halusinasi pendengaran, 20 $\%$ mengalami halusinasi penglihatan, dan $10 \%$ mengalami halusinasi lainnya.

Adapun gejala-gejala yang dapat di amati pada pasien halusinasi diantaranya bicara atau tertawa sendiri, marah-marah tanpa sebab, menunjuk kearah tertentu, ketakutan pada sesuatu yang tidak jelas, mencium seperti sedang membau-baui sesuatu, menutup hidung, sering meludah atau muntah, serta menggaruk-garuk permukaan kulit (Yusuf, Fitriyasari, Nihayati, 2015 ).

Empat faktor penyebab klien kambuh dan perlu di rawat dirumah sakit, menurut Sullinger 1988 dalam (Yosep \& Sutini 2016) pertama yaitu klien dimana diketahui bahwa klien yang gagal memakan obat secara teratur mempunyai kecenderungan untuk kambuh, kedua dokter sebagai pemberi resep yang diharapkan tetap waspada mengidentifikasi dosis teraupetik yang dapat mencegah kambuh dan efek samping, ketiga yaitu penanggung jawab klien setelah pulang ke rumah maka perawat puskesmas tetap bertanggung jawab atas program adaptasi klien di rumah sakit, dan yang keempat yaitu ketidak mampuan keluarga dalam 
merawat klien juga sebagai faktor penyebab kekambuhan klien.

Keluarga merupakan unit yang paling dekat dengan klien dan merupakan "perawat utama" bagi klien. Keluarga berperan dalam menentukan cara atau asuhan yang diperlukan klien di rumah. Keberhasilan perawat dirumah sakit dapat sia-sia jika tidak diteruskan dirumah karena dapat mengakibatkan klien harus dirawat kembali (kambuh). Peran serta keluarga sejak awal asuhan di RS akan meningkatkan kemampuan keluarga merawat klien di rumah sehingga kemungkinan dapat dicegah (Nasir \& Muhith 2011).

Setelah klien pulang kerumah, sebaiknya klien melakukan perawatan lanjutan pada puskesmas di wilayahnya yang mempunyai program kesehatan jiwa. Perawat komuniti yang menangani klien dapat menganggap rumah klien sebagai "ruangan perawatan". Perawat, klien, dan keluarga bekerjasama untuk membantu proses adaptasi klien di dalam keluarga dan masyarakat. Perawat membantu klien dan keluarga menyesuaikan diri di lingkungan keluarga, dalam hal sosialisasi, perawatan mandiri dan kemampuan memecahkan masalah. Perawat dapat membantu dan mengidentifikasi gejala kambuh dan segera melakukan tindakan sehingga dapat dicegah perawatan kembali di Rumah Sakit (Yosep \& Sutini, 2016)

Menurut Damaiyanti \& Iskandar (2014) peran perawat dalam menangani halusinasi salah satunya yaitu melakukan rencana asuhan keperawatan. Rencana asuhan keperawatan mencakup penerapan strategi pelaksanaan halusinasi baik secara individu maupun keluarga. Strategi pelaksanaann tindakan keperawatan melatih kemampuan intelektual tentang pola komunikasi dan pada saat dilaksanakan merupakan latihan kemampuan intelektual, psikomotor dan afektif. Strategi pelaksanaan pada pasien halusinasi mencakup kegiatan mengenal halusinasi, mengajarkan pasien menghardik halusinasi, minum obat dengan teratur, bercakap-cakap dengan orang lain saat halusinasi muncul, serta melakukan aktivitas terjadwal untuk mencegah halusinasi ( Keliat \& Akemat, 2014).

Keluarga yang mendukung pasien secara konsisten akan membuat pasien mampu mempertahankan program pengobatan secara optimal. Namun demikian, jika keluarga tidak mampu merawat pasien, pasien akan kambuh kembali sehingga untuk memulihkannya lagi akan sangat sulit. Untuk itu perawat harus memberikan asuhan keperawatan kepada keluarga agar keluarga mampu menjadikan pendukung yang efektif bagi pasien dengan halusinasi baik saat di Rumah Sakit maupun di rumah. Tindakan keperawatan yang ditujukan untuk keluarga pasien yang bertujuan agar keluarga dapat terlibat dalam perawatan pasien baik di rumah sakit maupun di rumah, dan keluarga dapat menjadi sistem pendukung yang efektif bagi pasien (Muhith, 2015).

Adapun tindakan keperawatan untuk keluarga yaitu strategi pelaksanaan (SP) keluarga yang terdiri dari 4 sesi. Strategi pelaksanaan pertama yaitu mendiskusikan masalah yang dihadapi keluarga dalam merawat pasien, memberikan pendidikan kesehatan tentang pengertian halusinasi, jenis halusinasi yang di alami pasien, tanda dan gejala halusinasi, menjelaskan cara perawatan pasien halusinasi, melatih keluarga cara menghardik serta menganjurkan keluarga membantu pasien sesuai jadwal dan member pujian. Strategi pelaksanaan kedua yaitu mengevaluasi kegiatan keluarga dalam merawat/melatih pasien menghardik, menjelaskan 6 benar minum obat, melatih keluarga memberikan/membimbing minum obat serta membantu pasien sesuai jadwal dan memberikan pujian. Strategi pelaksanaan ketiga yaitu mengevaluasi 
kegiatan keluarga dalam merawat/melatih pasien menghardik dan memberikan obat, menjelaskan cara bercakap-cakap dan melakukan kegiatan mengontrol halusinasi, melatih dan menyediakan waktu bercakap-cakap dengan pasien terutama saat halusinasi serta membantu pasien sesuai jadwal. Dan strategi pelaksanaan keempat yaitu mengevaluas kegiatan keluarga mulai dari sp satu hingga tiga, menjelaskan follow up ke RSJ/PKM, tanda kambuh, rujukan dan menganjurkan membantu pasien sesuai jadwal (FIK UI, 2009).

Penelitian terdahulu yang dilakukan oleh Kirana (2015) tentang pengaruh strategi pelaksanaan (SP) keluarga terhadap pengetahuan dan sikap keluarga tentang perawatan pasien halusinasi di Rumah Sakit Jiwa Daerah Provinsi Jambi. Penelitian ini merupakan penelitian kuantitatif dengan metode penelitian pre eksperiment dengan desain one group pretest dan posttest. Metode pengambilan sampel dengan cara purposive sampling dan jumlah sampel 20 orang. Hasil penelitian diketahui ada pengaruh antara strategi pelaksanaan (SP) keluarga terhadap pengetahuan dan sikap keluarga tentang perawatan halusinasi di Rumah Sakit Jiwa Propinsi Jambi. Penelitian selanjutnya juga meneliti strategi pelaksanaan dengan variabel kemampuan keluraga merawat pasien halusinasi untuk menyempurnakaan penelitian yang telah dilakukan.

Survey awal yang dilakukan peneliti di Poli Jiwa RSJD Provinsi Jambi pada tanggal 10 April 2017 adalah melalui wawancara kepada 5 keluarga yang membawa pasien untuk berobat, 5 keluarga menyatakan rutin datang ke Poli Jiwa untuk kontrol ulang. Sedangkan perawatan dirumah, 4 keluarga menyatakan hanya mengingatkan minum obat 3 kali sehari dan 1 keluarga selain mengingatkan untuk minum obat juga selalu mengingatkan cara menghardik apabila halusinasi pasien muncul. Dari 5 keluarga 4 diantaranya mengatakan belum pernah mendapatkan informasi mengenai strategi pelaksanaan keluarga sebelumnya. Sedangkan 1 keluarga pasien mengatakan pernah mendapatkan strategi pelaksanaan keluarga ketika di ruang rawat inap oleh salah satu mahasiswa. Di Poli Jiwa keluarga hanya di berikan informasi tentang rutin minum obat, sedangkan pengertian, tujuan hingga proses pelaksanaan strategi pelaksanaan keluarga tidak tersampaikan oleh perawat. Berdasarkan hasil wawancara dengan salah satu perawat yang ditemui mengatakan tidak melakukan strategi pelaksanaan keluarga di karenakan beban kerja yang banyak dan minimnya waktu untuk pelaksanaannya.

Berdasarkan uraian di atas peneliti tertarik untuk melakukan penelitian tentang Pengaruh Penerapan Strategi Pelaksanaan Keluarga Terhadap Kemampuan Keluarga Merawat Pasien Halusinasi di Kota Jambi Tahun 2017.

\section{METODE PENELITIAN}

Penelitian ini merupakan
penelitian kuantitatif dengan metode
penelitian pre eksperiment dengan
desain penelitian one group pretest dan
posttest. Penelitian ini dilakukan untuk
mengetahui pengaruh penerapan strategi
pelaksanaan keluarga terhadap
kemampuan keluarga merawat pasein
halusinasi. Instrument yang digunakan
dalam penelitian ini yaitu berupa
kuisioner wawancara sebanyak 5 item
dan lembar observasi sebanyak 5 item.
Penelitian ini telah dilakukan dari
tanggal 25 Juli sampai dengan 10
Agustus 2017 di Kota Jambi. Populasi
dalam penelitian ini sebanyak 3.642
responden dan sampel dalam penelitian
adalah 20 responden (Sugiyono, 2012).
Sampel yang dipilih merupakan sampel
yang telah memenuhi kriteria inklusi
Metode pengambilan sampel dengan
cara Purposive Sampling. Pengumpulan


data dilakukan dengan mesingisi kuisioner dan metode analisa data univariat dan bivariat menggunakan uji T-Test Dependen.

\section{HASIL DAN PEMBAHASAN}

Hasil penelitian dengan 20 responden tentang pengaruh penerapan strategi pelaksanaan keluarga terhadap kemampuan keluarga merawat pasien halusinasi di Kota Jambi. Adapun hasil yang diperoleh adalah sebagai berikut:

Tabel 1.1 .Gambaran karakteristik responden berdasarkan umur

\begin{tabular}{ccc}
\hline Usia & $\begin{array}{c}\text { Frekuensi } \\
\text { (orang) }\end{array}$ & $\begin{array}{c}\text { Persentase } \\
(\%)\end{array}$ \\
\hline 21-40 tahun & 11 & 55,0 \\
$\begin{array}{c}\text { (Dewasa awal) } \\
\text { 41-65 tahun } \\
\text { (Dewasa }\end{array}$ & 9 & 45,0 \\
$\begin{array}{l}\text { Madya) } \\
\text { Jumlah }\end{array}$ & 20 & 100,0 \\
\hline
\end{tabular}

Tabel 1.2 Jenis Kelamin

\begin{tabular}{ccc}
\hline $\begin{array}{c}\text { Jenis } \\
\text { Kelamin }\end{array}$ & Frekuensi & $\begin{array}{c}\text { Persentase } \\
(\%)\end{array}$ \\
\hline Laki-laki & 5 & 25,0 \\
Perempuan & 15 & 75,0 \\
Jumlah & 20 & 100,0 \\
\hline
\end{tabular}

Tabel 1.3 Pendidikan

\begin{tabular}{ccc}
\hline Pendidikan & Frekuensi & $\begin{array}{c}\text { Persentase } \\
(\%)\end{array}$ \\
\hline SD & 7 & 35,0 \\
SMP & 1 & 5,0 \\
SMA & 8 & 40,0 \\
PT & 4 & 20,0 \\
Jumlah & 20 & 100 \\
\hline
\end{tabular}

2. Gambaran Kemampuan Keluarga Merawat Pasien Halusinasi Sebelum diberikan Strategi Pelaksanaan Keluarga

Tabel 1.4 Distribusi rata-rata kemampuan keluarga merawat pasien halusinasi sebelum diberikan strategi pelaksanaan keluarga

\begin{tabular}{llllll}
\hline Me & Medi & Min - & SD & Stan & N \\
an & an & maks & & dar & \\
& & & & Error &
\end{tabular}

\begin{tabular}{lllllll}
\hline Sebe & 3.75 & 3.50 & $2-6$ & $\begin{array}{l}1.07 \\
0\end{array}$ & 0.239 & 2 \\
lum & & & & 0 & & 0
\end{tabular}

Berdasarkan tabel 1.4 , nilai ratarata kemampuan keluarga sebelum diberikan strategi pelaksanaan keluarga adalah 3.75 dengan median 3.50. Nilai minimum kemampuan keluarga adalah 2 dan nilai maksimal kemampuan keluarga adalah 6. Standar deviasi kemampuan responden adalah 1.070 dengan standar errornya 0.239 .

\section{3. . Gambaran Kemampuan Keluarga Merawat Pasien Halusinasi Sesudah diberikan Strategi Pelaksanaan Keluarga}

Tabel 1.5 Distribusi Rata-rata Kemampuan Keluarga Merawat Pasien Halusinasi Sesudah diberikan Strategi Pelaksanaan Keluarga

\begin{tabular}{lllllll}
\hline & $\begin{array}{l}\text { Me } \\
\text { an }\end{array}$ & $\begin{array}{l}\text { Medi } \\
\text { an }\end{array}$ & $\begin{array}{l}\text { Min }- \\
\text { maks }\end{array}$ & SD & $\begin{array}{l}\text { Stan } \\
\text { dar } \\
\text { Erro } \\
\text { r }\end{array}$ & N \\
& & & & & $\begin{array}{l}\text { 1.16 } \\
0.26\end{array}$ & 20 \\
\hline $\begin{array}{l}\text { Sebel } \\
\text { um }\end{array}$ & 5.75 & 5.00 & $4-8$ & 0 & \\
\hline
\end{tabular}

Berdasarkan tabel 1.5 , nilai ratarata kemampuan keluarga sesudah diberikan strategi pelaksanaan keluarga adalah 5.75 dengan median 5.00. Nilai 
minimum kemampuan keluarga adalah 4 dan nilai maksimal kemampuan keluarga adalah 8. Standar deviasi kemampuan responden adalah 1.164 dengan standar errornya 0.260 .

\section{Perbedaan kemampuan keluarga merawat pasien halusinasi sebelum dan sesudah diberikan strategi pelaksanaan keluarga di Kota Jambi}

\section{Tabel 1.6 Pengaruh Penerapan Strategi Pelaksanaan Keluarga Terhadap Kemampuan Keluarga Merawat Pasien Halusinasi Di Kota Jambi}

\begin{tabular}{cccccc}
\hline Variabel & Mean & SD & $\begin{array}{c}\text { Stand } \\
\text { ar } \\
\text { Error }\end{array}$ & $\begin{array}{c}\text { P- } \\
\text { Val } \\
\text { ue }\end{array}$ & N \\
\hline Kemampuan & 3.75 & $\begin{array}{c}1.07 \\
\text { sebelum }\end{array}$ & 0,239 & & \\
Kemampuan & 5.75 & 1.1 & 0.26 & 0,00 & 20 \\
sesudah & & 64 & 0 & 0 & \\
\hline
\end{tabular}

Hasil uji ststistik test berpasangan didapatkan hasil $p$-value $=0.000<0.05$, maka dapat disimpulkan bahwa setelah peneliti memberikan strategi pelaksanaan keluarga terdapat ada pengaruh terhadap kemampuan keluarga sebelum dan sesudah dilakukan strategi pelaksanaan keluarga yang berarti kemampuan keluarga mengalami perubahan yaitu peningkatan kemampuan keluarga merawat pasien dengan halusinasi, dengan selisih nilai 2.00 .

Hasil penelitian ini tidak sejalan dengan penelitian yang dilakukan oleh Suhita \& Fazrin (2015) dengan judul penelitian pengaruh health education tentang strategi pelaksanaan pada keluarga terhadap peran keluarga dalam membantu klien skizofrenia dalam mengontrol halusinasi di Kota Kediri. Dalam penelitian ini peneliti menggunakan sampel sebanyak 12 responden. Hasil dari penelitian ini tidak ada pengaruh health education tentang strategi pelaksanaan halusinasi pada keluarga terhadap peran keluarga membantu klien skizofrenia mengontrol halusinasi di Kota Kediri dengan pvalue $=0,1$.

Hasil penelitian ini sejalan dengan penelitian Kirana ( 2015 ) tentang pengaruh strategi pelaksanaan ( SP ) keluarga terhadap pengetahuan dan sikap keluarga tentang perawatan pasien halusinasi di Rumah Sakit Jiwa Daerah Provinsi Jambi. Penelitian ini merupakan penelitian kuantitatif dengan metode penelitian pre eksperiment dengan desain one group pretest dan posttest. Metode pengambilan sampel dengan cara purposive sampling dan jumlah sampel 20 orang. Hasil pengtahuan keluarga sebelum diberiakan strategi pelaksanaan keluarga yaitu dengan mean 5,45 dan sesudah diberikan strategi pelaksanaan keluarga dengan mean 9,10. Sikap keluarga sebelum di berikan strategi pelaksanaan keluarga yaitu dengan mean 26,80 dan setelah diberikan strategi pelaksanaan keluarga dengan mean 31,15. Hasil penelitian diketahui ada pengaruh antara strategi pelaksanaan ( SP ) keluarga terhadap pengetahuan dan sikap keluarga tentang perawatan halusinasi di Rumah Sakit Jiwa Provinsi Jambi.

Keluarga yang mendukung pasien secara konsisten akan membuat pasien mampu mempertahankan program pengobatan secara optimal. Namun demikian, jika keluarga tidak mampu merawat pasien, pasien akan kambuh kembali sehingga untuk memulihkannya lagi sangat sulit. Untuk itu perawat harus memberikan asuhan keperawatan keluarga agar keluarga mampu menjadikan pendukung yang efektif bagi pasien dengan halusinasi baik saat di rumah sakit maupun di rumah. Tindakan keperawatan yang ditujukan untuk keluarga pasien yang bertujuan agar keluarga dapat teribat dalam perawatan pasien baik di rumah skit maupun di rumah, dan keluarga dapat menjadi pendukung yang efektif bagi pasien (Muhith, 2015) 
Menurut Damaiyanti \& Iskandar (2014) peran perawat dalam menangani halusinasi salah satunya yaitu melakukan rencana asuhan keperawatan. Rencana asuhan keperawatan mencakup penerapan strategi pelaksanaan halusinasi baik secara individu maupun keluarga. Strategi pelaksanaan keperawatan merupakan rangkaian percakapan perawat dengan klien serta keluarga pada saat melakukan tindakan keperawatan. Strategi pelaksanaan tindakan keperawatan melatih kemampuan intelektual tentang pola komunikasi dan pada saat pelaksanaan merupakan latihan kemampuan yang integral antara intelektual, psikomotor dan afektif.

Strategi pelaksanaan keluarga pasien dengan halusinasi terdiri dari empat tahapan diantaranya tahap pertama yaitu mendiskusikan masalah yang dirasakan dalam merawat klien serta melatih cara menghardik halusinasi. Tahap kedua yaitu menjelaskan 6 benar cara memberikan obat, selanjutnya tahap ketiga menjelaskan cara bercakap-cakap dan melakukan kegiatan untuk mengontrol halusinasi. Dan tahapan keempat yaitu menjelaskan follow up ke RSJ/PKM, tanda kambuh, rujukan dan menganjurkan membantu pasien sesuai jadwal. (FIK UI, 2009).

Hasil penelitian ini terjadi perubahan atau meningkatnya kemampuan keluarga merawat pasien dengan halusinasi yang di ukur melalui penerapan strategi pelaksanaan keluarga. Hasil penelitian ini menyatakan bahwa strategi pelaksanaan keluarga dapat digunakan sebagai upaya untuk meningkatkan kemampuan keluarga dalam merawat dengan halusinasi di Kota Jambi.

$$
\text { Menurut Yosep }
$$

Kemampuan keluarga tersebut sangat berpengaruh terhadap pasien dalam mengontrol halusinasi. Pentingnya perawatan dilingkungan keluarga dapat dipandang dari berbagai segi yaitu keluarga merupakan suatu konteks dimana individu memulai hubungan interpersonal. Oleh karena itu setelah pasien tidak lagi di rawat di rumah sakit maka perawatan selanjutnya akan dilakukan oleh keluarga. Apabila keluarga tidak memiliki kemampuan untuk merawat pasien dengan halusinasi maka kecenderungan pasien untuk kambuh akan semakin besar. Keterlibatan keluarga dalam perawatan sangat menguntungkan proses pemulihan pasien.

Menurut peneliti adanya perubahan yang signifikan antara sebelum di lakukan intervensi dan setelah dilakukan intervensi dapat terjadi karena informasi yang disampaikan masih diingat sehingga dapat segera memperbaikinya, informasi yang diberikan member pemahaman baru mengenai cara merawat atau mengontrol halusinasi pasien.

Upaya-upaya yang perlu dilakukan oleh petugas kesehatan untuk meningkatkan kemampuan keluarga dalam merawat pasien dengan halusinasi adalah dengan melakukan penerapan strategi pelaksanaan keluarga. Hal ini bertujuan untuk membantu proses penyembuhan pasien ketika pasien berada dirumah.

\section{SIMPULAN}

Kesimpulan dalam penelitian ini dapat dilihat dari hasil uji statistic paired t-test pada kemampuan keluarga didapatkan $p$-value $=0.000<0.05$, yang artinya setelah peneliti memberikan strategi pelaksanaan keluarga terdapat ada pengaruh terhadap kemampuan keluarga sebelum dan sesudah dilakukan strategi pelaksanaan keluarga yang berarti kemampuan keluarga mengalami perubahan yaitu peningkatan kemampuan keluarga merawat pasien dengan halusinasi, dengan selisih nilai 2.00 . 


\section{SARAN}

\begin{abstract}
Diharapkan untuk peneliti selanjutnya untuk meneliti strategi pelaksanaan keluarga dengan waktu yang lebih lama agar peningkatan kemampuan keluarga lebih efektif sehingga kemungkinan pasien untuk terkontrol semakin baik.
\end{abstract}

\section{DAFTAR PUSTAKA}

Andarmoyo.2012.Keperawatan Keluarga.Graha Ilmu.Yogyakarta Andruyani, Sulistyawaty, Huyati (2015). Hubungan Tingkat Pengetahuan Keluarga Tentang Perawatan Halusinasi Dengan Tingkat Kekambuhan Pasien Halusinasi Di Rumah Sakit Jiwa Daerah Surakarta. Jurnal

Baradero, Dayrit \& Maratning.2016. Dasar-dasar Keperawatan Jiwa.Salemba medika.Jakarta

Damaiyanti \& Iskandar.2014.Asuhan Keperawatan Jiwa.Refika Aditama.Bandung

Davies \& Craig.2009.ABC Kesehatan Mental.EGC.Jakarta

Direja.2011.Buku Ajar Asuhan Keperawatan Jiwa.Nuha Medika.Yogyakarta

FIK UI.2009. Modul Praktik Ners Spesialis Keperawatan Jiwa.Tidak Dipublikasikan

Keliat \& Akemat. 2014.Model Praktek Keperawatan Profesional Jiwa.EGC.Jakarta

Kirana (2015). Pengaruh Strategi Pelaksanaan (SP) Keluarga Terhadap Pengetahuan dan Sikap Keluarga Tentang Perawatan Pasien Halusinasi di Rumah Sakit Jiwa Daerah Provinsi Jambi. Skripsi
Muhith, Abdul. 2015. Pendidikan Keperawatan Jiwa. CV Andi Offset. Yogyakarta

Nasir \& Muhith.2011.Dasar-dasar Keperawatan

Jiwa.Salemba.Medika.Jakarta

Notoadmodjo, S.2010.Metodologi Penelitian Kesehatan.Rineka Cipta.Jakarta

Notoadmodjo, S.2012.Ilmu Perilaku Kesehatan Edisi.Rineka Cipta.Jakarta

Rekam Medik Rumah Sakit Jiwa Daerah Provinsi Jambi Tahun 2016. Jumlah Penyakit Skizofrenia di Klinik Jiwa Rumah Sakit Jiwa Daerah Provinsi Jambi Tahun 2014 - 2016. Jambi

Riset Kesehatan Dasar (RISKESDAS). 2013. Badan Penelitian Dan Pengembangan Kesehatan. Jakarta. Diakses pada 5 Januari 2017

Setiawati \& Dermawan.2008.Asuhan Keperawatan Keluarga.Trans Info Media.Jakarta

STIKBA. 2015. Pedoman Penulisan Skripsi. Sekolah Tinggi Ilmu Kesehatan Baiturrahim. Jambi

Sugiyono.2012.Metode Penelitian Kuantitatif dan Kualitatif.Alfabeta.Bandung

Suhita \& Fazrin (2015). Pengaruh Health Education Tentang Stategi Pelaksanaan Pada Keluarga Terhadap Peran Keluarga Dalam Membantu Klien Skizofrenia Dalam Mengontrol Halusinasi di Kota Kediri. Jurnal

Yosep \& Sutini.2016.Buku Ajar Keperawatan Jiwa.Refika Aditama.Bandung

Yusuf, Fitria, Nihayati. 2015. Buku Ajar Keperawatan Kesehatan Jiwa.Salemba Medika.Jakarta 